\title{
PENERAPAN MODEL PEMBELAJARAN VISUALIZATION, AUDITORY, KINESTHETIC TERHADAP KEMAMPUAN PENALARAN MATEMATIS SISWA SMP
}

\author{
Mariyam $^{1}$, Rika Wahyuni², Muhammad Andre Setiawan ${ }^{3}$ \\ ${ }_{1,2,3}$ Pendidikan Matematika, STKIP Singkawang \\ 1email: mariyam.180488@gmail.com \\ ${ }^{2}$ email: Rikawahyuni142@gmail.com
}

\begin{abstract}
This study aims to determine the mathematical reasoning abilities, activities and motivation of students by applying the Visualization Auditory Kinesthetic (VAK) learning model. This type of experimental research with the design of the Nonequivalent Pretest-Posttest Control Group Design. The experimental and control classes were given a pretest and a posttest to see the difference in improvement between the two. The population in this study were students of class VIII and the sample was not chosen purely randomly, namely by cluster random sampling (random class) and two classes were chosen. Data analysis using statistical tests namely Mann Whutney U-Test and descriptive analysis in the form of a percentage formula and the average score. The results of data analysis show that: (1) There is a difference in the increase in students' mathematical reasoning abilities, and the increase in the experimental class is higher than the control class; (2) Student learning activities in each indicator are in the very high category and the overall average is $88.075 \%$; (3) The average student motivation in each indicator is in the high category and the overall student average is 4.00.
\end{abstract}

Keywords: Visualization Auditory Kinesthetic, Reasoning, Activity, Motivation

\section{PENDAhULUAN}

Kurikulum 2013 menjadi acuan pelaksanaan pendidikan di Indonesia sampai pada saat ini. Ciri khas dari Kurikulum tersebut yaitu pelaksanaan proses pembelajaran harus mengacu pada pendekatan ilmiah yang dikenal dengan pendekatan scientific (mengamati, menanya, menalar, mencoba, dan membentuk jejaring). Dalam dokumen National Council of Teacher of Mathematic (NCTM, 2000) juga menyatakan bahwa belajar untuk berkomunikasi (mathematical communication), belajar untuk bernalar (mathematical reasoning), belajar untuk memecahkan masalah (mathematical problem solving), belajar untuk mengaitkan ide (mathematical connection), dan pembentukan sikap positif terhadap matematika (positive attitude toward mathematics). Sejalan dengan hal tersebut, dalam Permendikbud nomor 59 tahun 2014 dinyatakan bahwa tujuan dari matematika adalah dapat menggunakan penalaran pada sifat, melakukan manipulasi matematika baik dalam penyederhanaan, maupun menganalisa komponen yang ada dalam pemecahan masalah dalam konteks matematika maupun di luar matematika (kehidupan nyata, ilmu, dan teknologi) yang meliputi kemampuan memahami masalah, membangun model matematika, menyelesaikan model dan menafsirkan solusi yang diperoleh termasuk dalam rangka memecahkan masalah dalam kehidupan sehari-hari. Proses bernalar menjadi satu diantara lima langkah atau tahapan pokok dalam belajar memahami materi. Hal ini menjadikan proses bernalar atau kemampuan penalaran menjadi tujuan pembelajaran, tidak terkecuali tujuan pembelajaran matematika. 
Sumarmo (2007) mengungkapkan bahwa kemampuan penalaran merupakan proses berfikir dalam penarikan kesimpulan. Sehingga diharapkan dengan kemampuan bernalarnya maka seseorang dimungkinkan untuk dapat memahami suatu konsep yang kemudian digunakan untuk memecahkan masalah. Dengan demikian sudah jelas bahwa kemampuan penalaran dalam mempelajari matematika penting untuk dimiliki oleh siswa, karena kemampuan tersebut digunakan untuk menganalisa komponen-komponen yang ada dalam suatu permasalahan sebelum memecahkan permasalahan tersebut dan berperan dalam menumbuhkembangkan sikap positif terhadap matematika.

Kecenderungan siswa tidak menyukai matematika, karena menganggap beberapa permasalahan yang diberikan susah untuk dipahami, maka dari itu untuk menyukai permasalahan tersebut diperlukaan proses pengenalan masalah yang satu diantaranya ditempuh dengan bernalar. Menurut Mariyam dan Wahyuni (2016) apabila kemampuan penalaran tidak dikembangkan pada siswa, maka bagi siswa matematika hanya akan menjadi materi yang mengikuti serangkaian prosedur dan meniru contoh tanpa mengetahui maknanya, hal yang demikian menjadi matematika sebagai suatu hal yang monoton, terurut, dan bersifat prosedural. Kusumah (dalam Mikrayanti, 2012) menyebutkan bahwa kemampuan penalaran matematis adalah kemampuan menarik kesimpulan dalam sebuah argumen dan cara berpikir yang merupakan penjelasan dalam upaya memperlihatkan hubungan antara dua hal atau lebih berdasarkan sifat-sifat atau hukum-hukum tertentu yang diakui kebenarannya, dengan menggunakan langkah-langkah tertentu yang berakhir dengan sebuah kesimpulan. Dengan kemampuan tersebut, maka siswa dilatih untuk memahami matematika secara lebih menyeluruh dan lebih mendalam, sebelum memutuskan cara yang tepat untuk menyelesaikannya. Sehingga siswa yang memiliki kemampuan penalaran yang baik akan lebih mudah memahami materi matematika dan menyelesaikannya dengan benar, demikian pula sebaliknya. Dengan kata lain materi matematika dipahami melalui penalaran dan kemampuan penalaran dilatih dan dipahami melalui matematika.

Namun beberapa hasil penelitian menunjukan bahwa kemampuan penalaran matematis di sekolah masih rendah. Berdasarkan penelitian yang dilakukan oleh Musthafa, dkk (2014:4) menunjukan bahwa kemampuan penalaran matematis masih belum tuntas untuk tiap-tiap indikator, secara rinci hasil yang diperoleh antara lain 1) mengajukan dugaan (57\%); 2) melakukan manipulasi matematika $(57 \%)$; 3) menarik kesimpulan, menyusun bukti, memberikan alasan atau bukti terhadap Beberapa Solusi Data deskriptif aspek menarik kesimpulan, menyusun bukti, memberikan alasan atau bukti terhadap beberapa solusi $(57 \%), 4)$ menarik kesimpulan dari suatu kenyataan $(25 \%)$, 5) memeriksa kesahihan suatu argumen $(59 \%), 6)$ menentukan pola atau sifat dari gejala matematis untuk membuat generalisasi (34\%). Hal serupa juga terjadi pada siswa di SMP Negeri 4 singkawang, berdasarkan hasil prariset yang dilakukan oleh peneliti terlihat bahwa kemampuan penalaran matematis siswa masih rendah pada tiap indikatornya, bahkan belum ada yang mencapai $50 \%$. Dugaan rendahnya kemampuan penalaran siswa disebabkan karena siswa kurang dilibatkan dalam memahami suatu konsep.Berdasarkan observasi di kelas VII D SMP Negeri 4 Singkawang ditemukan bahwa konsep materi ataupun rumus diberikan secara langsung, sehingga pada saat proses pembelajaran menalar yang seharusnya menjadi proses memikirkan tentang konsep ataupun rumus apa yang akan digunakan, menjadi proses berhitung atau mendengarkan penjelasan guru saja. Hal tersebut ternyata juga berdampak pada motivasi sebagian besar siswa dalam kelas tersebut. Siswa hanya fokus mendengarkan, 
mencatat dan mengerjakan soal rutin.Bahkan saat maju kedepan siswa tidak menjelaskan hasil pekerjaannya.

Sebagai solusi dari permasalahan tersebut, maka dapat ditegaskan bahwa usaha perbaikan proses pembelajaran melalui upaya pemilihan model pembelajaran yang tepat dan inovatif dalam pembelajaran matematika di sekolah merupakan suatu kebutuhan yang sangat penting untuk dilakukan. Salah satu model pembelajaran yang diduga dapat digunakan untuk memperbaiki kualitas proses dan hasil belajar adalah model VAK (Visualization, Auditory, Kinesthetic). Menurut Huda (2013:289) model pembelajaran VAK merupakan model pembelajaran "multi-sensorik yang melibatkan tiga unsur gaya belajar, yaitu penglihatan, pendengaran, dan gerakan". Selanjutnya menurut Lestari dan Yudhanegara (2015:58) model pembelajaran VAK merupakan model pembelajaran yang menekankan bahwa belajar haruslah memanfaatkan alat indra yang dimiliki siswa yaitu menggunakan alat indera dengan cara melihat, mendengar dan melakukan aktivitas atau gerakan anggota tubuh lainnya.Proses pembelajaran dengan model VAK dirancang untuk menciptakan ligkunngan belajar yang menyenangkan, menantang kemampuan berfikir dan manantang bagi siswa. Sebagai contoh pada tahap visualization siswa dihadapkan dengan berbagai gambar tentang relasi dan fungsi yang berkaitan dengan kehidupan anak, dan selanjutnya meminta siswa untuk mengklasifikasikan permasala tersebut termasuk ke dalam contoh fungsi atau bukan. Hal ini sesuai dengan satu diantara beberapa indikator kemampuan penalaran matematis siswa yaitu siswa diharapkan dapatmemberi penjelasan dengan model, fakta, sifat-sifat dan hubungan. Hanafiah dkk (2009) menyatakan proses aktivitas pembelajaranharus melibatkan seluruh aspek psikofis peserta didik, baik jasmani maupun rohanisehingga akselerasi perubahan perilakunya dapat terjadi secara cepat, tepat, mudah dan benar. Selain itu diharapkan juga dengan model pembelajaran VAK siswa memiliki motivasi yang tinggi dalam belajar sehingga dapat mengubah aktivitas belajarnya menjadi lebih aktif. Aktivitas siswa dalam pembelajaran diamati ketika diterapkannya model pembelajaran VAK.

\section{METODE PENELITIAN}

Jenis penelitian ini adalah jenis penelitian kuantitatif dengan metode eksperimen. Desain penelitian yang digunakan dalam penelitian ini The Nonequivalent Pretest-Posttest Control Group Design. Terdapat dua kelas dalam penelitian ini yaitu kelas eksperimen kelas kontrol. Adapun sekolah yang menjadi tempat penelitian adalah SMP Negeri 4 Singkawang kelas VIII Kelurahan Jawa Kecamatan Singkawang Tengah. Populasi dalam penelitian ini adalah seluruh kelas VIII SMP Negeri 4 Singkawang yang terdiri dari delapan kelas dan berjumlah 200 siswa. Teknik pengambilan sampel pada penelitian ini dipilih secara acak murni, yaitu dengan cluster random sampling (acak kelas). Setelah populasi dinyatakan homogeny, maka dilipihlah 2 kelas untuk dijadikan sampel penelitian. Adapun yang menjadi kelas eksperimen adalah kelas VIII D dan kelas kontrol adalah kelas VIII E.

Instrumen pengumpul data yang digunakan dalam penelitian ini adalah tes tertulis berbentuk soal uraian yang mengandung empat indikator kemampuan penalaran, lembar observasi untuk mengamati aktivitas belajar siswa yang dilihat dari lima indikator aktivitas belajar, dan lembar angket motivasi yang dibuat dengan mengacu pada 5 indikator motivasi untuk mengetahui motivasi siswa setelah menggunakan model pembelajaran VAK. Lembar angket motivasi berisi pernyatan positif dan negatif dengan lima kategori jawaban yaitu Sangat Setuju (SS), Setuju (S), (Ragu-ragu), Tidak Setuju (TS), dan Sangat Tidak Setuju (STS). Teknik analisis data yang digunakan dalam penelitian ini adalah analisis kuantitatif dengan statistika. Dalam penelitian ini digunakan uji N-gain yang kemudian dilanjutkan dengan uji Man Whitney U-Test (karena kedua data berdistribusi tidak normal) untuk melihat 
Penerapan Model Pembelajaran Visualization, Auditory, Kinesthetic Terhadap Kemampuan Penalaran Matematis Siswa SMP

Mariyam $^{1}$, Rika Wahyuni ${ }^{2}$, Muhammad Andre Setiawan ${ }^{3}$

perbedaan peningkatan kemampuan penalaran matematis siswa antara kelas eksperimen dan kelas kontrol. Sedangkan untuk menjawab masalah aktivitas digunakan rumus persentase sebaran siswa dengan rumus sebagai berikut:

$$
\text { Persentase Aktivitas }\left(\mathrm{PA}_{\mathrm{k}}\right)=\frac{\text { Iumlah yang diperoleh pengamat }}{\text { Jumlah skor keseluruhan }} \mathrm{X} 100 \%
$$

Tabel 1. Kriteria Persentase Aktivitas Siswa

\begin{tabular}{lc}
\hline Jumlah Persentase & Kriteria \\
\hline $75 \%<P A k \leq 100 \%$ & Sangat Aktif \\
$50 \%<P A k \leq 75 \%$ & Aktif \\
$25 \%<P A k \leq 50 \%$ & Cukup Aktif \\
$0 \%<P A k \leq 25 \%$ & Kurang Aktif \\
\hline
\end{tabular}

Sedangkan untuk motivasi digunakan rumus rata-rata yaitu:

(Arkasari, Hobri, \& Sugiarti, 2014)

Rata-rata $=\frac{\text { Iumlah Skor tiap Indikator }}{\text { Skor Maks } x \text { Banyak Siswa }}$

Tabel 2. Kriteria Motivasi Belajar Siswa

\begin{tabular}{cc}
\hline Validitas & Interpretasi \\
\hline $4,3 \leq \bar{x} \leq 5,0$ & Sangat Tinggi \\
$3,5 \leq \bar{x} \leq 4,2$ & Tinggi \\
$2,7 \leq \bar{x} \leq 3,4$ & Cukup \\
$1,9 \leq \bar{x} \leq 2,6$ & Kurang \\
$1,0 \leq \bar{x} \leq 1,8$ & Sangat Kurang \\
\hline
\end{tabular}

\section{HASIL DAN PEMBAHASAN}

\section{Kemampuan Penalaran Matematis Siswa}

Hasil pengumpulan data selama penelitian diperoleh data hasil Pretest dan posttest (berupa skor) dari kelas yang diajarkan dengan model pembelajaran VAK (kelas eksperimen) dan pembelajaran langsung (kelas kontrol) yang menunjukkan kemampuan penalaran matematis siswa pada materi relasi dan fungsi. Adapun soal Pretest dan posttest yang diberikan berbentuk tes kemampuan penalaran matematis sebanyak empat soal dengan empat indikator yaitu: 1) menarik kesimpulan logis; 2) memberikan penjelasan dengan model, fakta, sifat-sifat dan hubungan; 3) memperkirakan jawaban dan solusi; 4) menggunakan pola dan hubungan untuk menganalisis situasi atau membuat analogi dengan generalisasi. Berdasarkan hasil perhitungan diperoleh rata-rata nilai Pretest dan posttest pada kedua kelas meningkat, namun rata-rata di kelas eksperimen jauh lebih tinggi dibandingkan kelas kontrol. Berikut rekapitulasi akan disajikan pada Tabel 3.

Tabel 3. Data Hasil Pretest dan Posttest pada Kelas Eksperimen dan Kelas Kontrol

\begin{tabular}{lllll}
\hline \multirow{2}{*}{ Keterangan } & \multicolumn{2}{l}{ Kelas eksperimen } & \multicolumn{2}{l}{ Kelas control } \\
\cline { 2 - 5 } & Pretest & Posttest & Pretest & Posttest \\
\hline
\end{tabular}




\begin{tabular}{lrrrr}
\hline Rata-rata & 50,79 & 87,75 & 30,50 & 55,82 \\
Standar Deviasi & 9,33 & 9,34 & 13,41 & 8,94 \\
\hline
\end{tabular}

Berdasarkan Tabel 3 terlihat bahwa di kelas eksperimen maupun kelas kontrol menyatakan bahwa nilai posttest lebih tinggi dibandingkan nilai pretest. Hal ini menunjukan bahwa di kedua kelas tersebut kemampuan penalaran matematis siswa meningkat. Peningkatan kemampuan penalaran matematis siswa diukur dengan uji Indeks Gain. Hasil perhitungan indeks gain berdasarkan setiap indikator kemampuan penalaran matematis siswa kelas eksperimen dan kelas kontrol dapat dilihat pada Gambar 1 berikut:

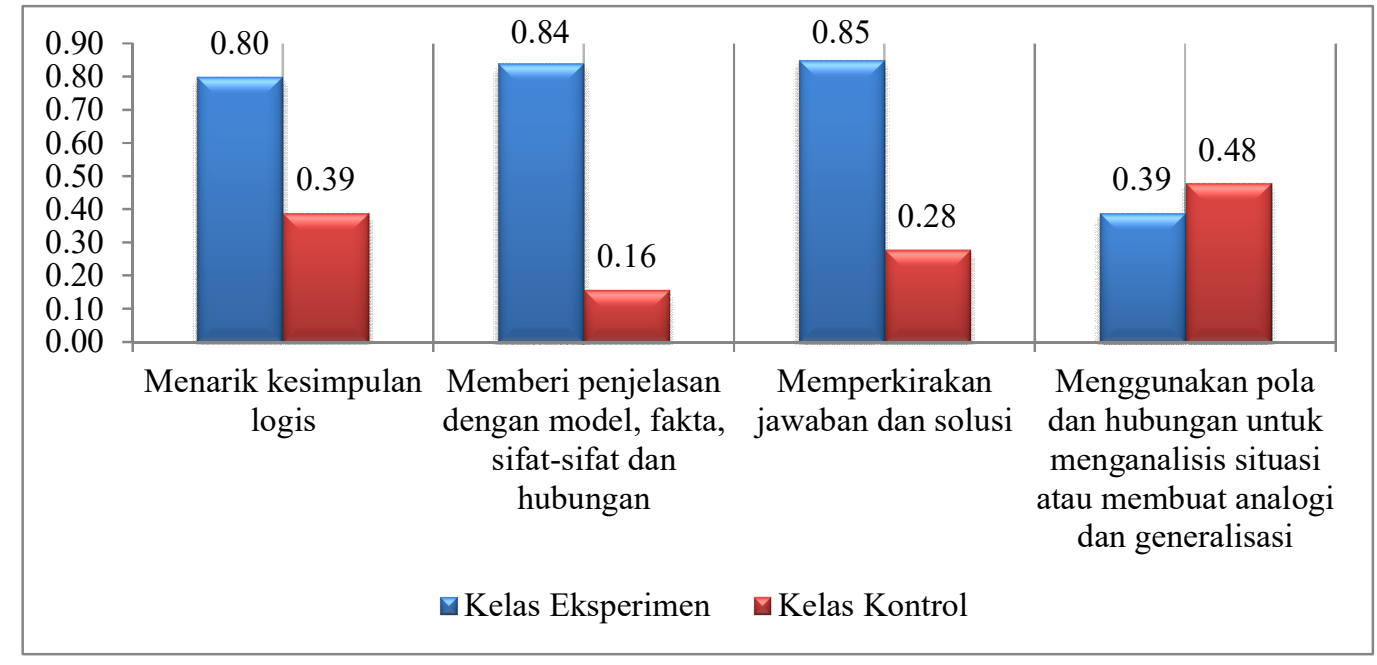

\section{Gambar 1. Diagram Batang Perhitungan Indeks Gain pada Tiap Indikator Kemampuan Penalaran Matematis}

Berdasarkan Gambar 1 diketahui bahwa rata-rata nilai Gain pada tiap indikator kemampuan penalaran matematis siswa kelas eksperimen lebih tinggi daripada rata-rata indikator kemampuan penalaran matematis siswa kelas kontrol. Selanjutnya diperoleh rata-rata nilai Gain untuk keseluruhan indikator kemampuan penalaran matematis siswa pada kelas eksperimen sebesar 0,72 dan di kelas control diperoleh sebesar 0,33. Hal ini menunjukkan bahwa secara deksriptif rata-rata indeks gain antara kelas kontrol dan kelas eksperimen berbeda, namun secara inferensial nilai tersebut belum tentu memiliki perbedaan yang signifikan. Maka dari itu, untuk melihat perbedaan peningkatan antara kelas eksperimen dan kelas kontrol digunakan uji statistik inferensial yang sebelumnya dilakukan uji normalitas dan uji homogenitas. Berikut hasil uji normalitas untuk data $\mathrm{N}$-gain kelas eksperimen dan kontrol disajikan ada Tabel 4.

Tabel 4. Rekapitulasi Perhitungan Uji Normalitas

\begin{tabular}{ccccc}
\hline Kelompok & $\mathrm{N}$ & $x^{2}$ Hitung & $x^{2}$ Tabel & Kesimpulan \\
\hline Eksperimen & 28 & 63,3620 & 11,070 & $\begin{array}{c}\text { Data Berdistribusi Tidak } \\
\text { Normal }\end{array}$ \\
Kontrol & 28 & 60,6018 & 11,070 & $\begin{array}{c}\text { Data Berdistribusi ttidak } \\
\text { Normal }\end{array}$
\end{tabular}


Penerapan Model Pembelajaran Visualization, Auditory, Kinesthetic Terhadap Kemampuan Penalaran Matematis Siswa SMP

Mariyam $^{1}$, Rika Wahyuni ${ }^{2}$, Muhammad Andre Setiawan ${ }^{3}$

Beradasarkan Tabel 4 diketahui bahwa data N-gain kelas eksperimen dan kelas kontrol berdistribusi tidak normal. Maka untuk mengetahui perbedaan peningkatan antara kedua kelas tersebut, digunakan uji Man Whitney U-Test. Adapun rekapitulasi hasil perhitungan perbedaan penggunaan model pembelajaran VAK dan model pembelajaran langsung terhadap kemampuan penalaran matematis siswa dapat dilihat pada Tabel 5 berikut.

Tabel 5. Rekapitulasi Perhitungan Uji Man Whitney U-Test

\begin{tabular}{|c|c|c|c|c|c|c|}
\hline Keterangan & $n_{1}$ & $n_{2}$ & $U_{1}$ & $\mathbf{U}_{2}$ & $\mathbf{E}(\mathbf{U})$ & $\operatorname{Var}(\mathbf{U})$ \\
\hline $\begin{array}{l}\text { Skor } \\
\mathbf{Z}_{\text {hitung }} \\
-\mathbf{Z}_{\text {tabel }}\end{array}$ & 28 & 28 & 10 & $\begin{array}{c}770,5 \\
-6,25 \\
-0,975\end{array}$ & 392 & 3724 \\
\hline
\end{tabular}

Berdasarkan Tabel 5 terlihat bahwa nilai $Z_{\text {hitung }}=-6,25$. Berdasarkan kriteria pengujian maka penggunaan model pembelajaran VAK dan model pembelajaran langsung terhadap kemampuan penalaran matematis siswa dikatakan memiliki perbedaan peningkatan apabila $Z_{\text {hitung }}<-Z_{\text {tabel, }}$, sebaliknya dikatakan tidak ada perbedaan apabila $-Z_{\text {tabel }} \leq Z_{\text {hitung }} \leq Z_{\text {tabel }}$. Diketahui $Z_{\text {hitung }}<-Z_{\text {tabel }}$ atau $-6,25<-0,975$, maka disimpulkan bahwa terdapat perbedaan peningkatan kemampuan penalaran matematis siswa antara kelas yang menggunakan model pembelajaran VAK dan kelas yang menggunkan model pembelajaran langsung pada materi relasi dan fungsi kelas VIII SMP Negeri 4 Singkawang. Perbedaan peningkatan kemampuan penalaran matematis antara kelas eksperimen dan kelas kontrol disebabkan pada proses pembelajaran dengan model pembelajaran VAK memiliki fase-fase yang membuat siswa lebih aktif dan lebih dapat memahami materi. Guru tidak sekadar memberikan pengetahuan kepada siswa, melainkan memfasilitasi siswa untuk membangun pengetahuannyasendiri sehingga siswa memiliki pemahaman yang lebih mantap terhadap materi relasi dan fungsi. Selain itu, model pembelajaan pembelajaran VAK juga dirancang untuk mengoptimalkan alat indera siswa dalam menyerap materi pembelajaran yang disampaikan. Sedangkan pada kelas kontrol, kegiatan pembelajaran yang dilakukan cenderung monoton meskipun guru lebih mudah dalam melakukan pengelolaan kelas. Pembelajaran yang membosankan akan membuat siswa kurang tertarik untuk pembelajaran yang berikutnya sehingga hasil belajar yang dicapai belum optimal. Salah satu kelebihan model pembelajaran pembelajaran VAK yang diungkapkan oleh Kartikasari (2011) adalah siswa dapat belajar dengan baik jika mereka dapat melihat contoh dari dunia nyata, diagram, peta gagasan, ikon, gambar, dan gambaran dari segala macam ketika mereka sedang belajar.

\section{Aktivitas Belajar Siswa}

Pengamatan aktivitas hanya dilakukan di kelas eksperimen dan dilakukan selama dua kali pertemuan dengan 3 orang pengamat. Ada 5 indikator aktivitas belajar yang diamati yaitu visual activities oral activities, listening activities, writing activities dan drawing activities. Persentase hasil pengamatan aktivitas siswa disajikan dalam Tabel 6 berikut.

Tabel 6. Rekapitulasi Perhitungan Aktivitas Belajar Siswa

\begin{tabular}{ccccc}
\hline No & $\begin{array}{l}\text { Kategori } \\
\text { Pengamatan }\end{array}$ & Pertemuan 1 & Pertemuan 2 & Rata-rata \\
\hline 1 & Visual Activities & $84,52 \%$ & $84,13 \%$ & $\mathbf{8 8 , 0 7 5 \%}$ \\
2 & Oral Activities & $83,33 \%$ & $84,94 \%$ &
\end{tabular}




\begin{tabular}{lcrr}
\hline 3 & Listening Activities & $82,54 \%$ & $84,92 \%$ \\
4 & Writing Activities & $90,48 \%$ & $94,06 \%$ \\
5 & Drawing Activities & $93,41 \%$ & $98,41 \%$ \\
\hline & Rata-rata & $86,86 \%$ & $89,29 \%$ \\
\hline
\end{tabular}

Berdasarkan Tabel 6 dapat dilihat bahwa persentase rata-rata aktivitas pada pertemuan pertama dan kedua data persentase aktivitas siswa mengalami peningkatan dan pada tiap indicator aktivitas diperoleh persentase di atas $80 \%$ yang beradasarkan kategori aktivitas berada pada kategori sangat tinggi yang dapat diartikan aktivitasnya aktif. Selanjutnya ratarata dari lima indikator aktivitas yang diamati diperoleh rata-rata sebesar $88,075 \%$. Besarnya persentase aktif disebabkan model pembelajaran VAK yang mampu merangsang siswa dalam mengemukakan ide-ide yang mereka miliki, menyelesaikan permasalahan sesuai strategi yang mereka kuasai, saat bertanya siswa merasa lebih yakin dan siswa merasa percaya diri saat menyelesaikan permasalahan sampai tuntas sehingga siswa lebih aktif dalam kegiatan pembelajaran tanpa merasa ragu memaparkan jawaban siswa di depan kelas. Sehingga dapat disimpulkan bahwa pembelajaran menggunakan model pembelajaran VAK mampu membuat siswa aktif selama proses pembelajaran berlangsung. Sejalan dengan pernyataan di atas, Shoimin (2014) mengungkapkan bahwa kelebihan dari model pembelajaran VAK diantaranya adalah siswa lebih berpartisipasi aktif dalam pembelajaran dan sering mengekspresikan idenya.

\section{Motivasi Belajar Siswa}

Angket motivasi hanya dilakukan di kelas eksperimen dan diberikan setelah proses pembelajaran pada pertemuan kedua selesai. Angket motivasi belajar dalam penelitian ini merupakan angket tertutup dan siswa hanya memilih satu jawaban dari 5 pilihan yang diberikan (sangat setuju, setuju, ragu-ragu, tidak setuju dan sangat tidak setuju) yang telah disediakan. Angket motivasi yang digunakan berupa pernyataan positif dan pernyataan negatif yang berjumlah 16 pernyataan dan terdiri dari 5 indikator motivasi belajar. Hasil perhitungan rata-rata angket motivasi belajar siswa pada pernyataan positif pada kelas eksperimen dapat dilihat pada Tabel 7.

Tabel 7. Rekapitulasi Hasil Angket Motivasi Belajar Siswa untuk Pernyataan Positif

\begin{tabular}{|c|c|c|c|c|c|c|c|}
\hline \multirow{2}{*}{ Indikator } & \multicolumn{5}{|c|}{ Jumlah Siswa tiap Pilihan } & \multirow{2}{*}{$\begin{array}{l}\text { Rata- } \\
\text { rata }\end{array}$} & \multirow[t]{2}{*}{ Kriteria } \\
\hline & SS & $\mathrm{S}$ & $\mathrm{RR}$ & TS & STS & & \\
\hline $\begin{array}{l}\text { 1. Adanya dorongan dan } \\
\text { kebutuhan dalam belajar }\end{array}$ & 20 & 22 & 10 & 3 & 1 & 4,01 & Tinggi \\
\hline $\begin{array}{l}\text { 2. Menunjukan perhatian } \\
\text { dan minat terhadap tugas- } \\
\text { tugas yang diberikan }\end{array}$ & 31 & 46 & 5 & 1 & 1 & 4,35 & Sangat Tinggi \\
\hline 3. Tekun menghadapi tugas & 16 & 21 & 11 & 6 & 2 & 3,76 & Tinggi \\
\hline $\begin{array}{l}\text { 4. Ulet menghadapi } \\
\text { kesulitan }\end{array}$ & 23 & 18 & 5 & 8 & 2 & 3,96 & Tinggi \\
\hline $\begin{array}{l}\text { 5. Adanya hasrat dan } \\
\text { keinginan berhasil }\end{array}$ & 35 & 36 & 13 & 0 & 0 & 4,26 & Sangat Tinggi \\
\hline Rata-Rata Keseluruhan & & & & & & 4,07 & Tinggi \\
\hline
\end{tabular}


Penerapan Model Pembelajaran Visualization, Auditory, Kinesthetic Terhadap Kemampuan Penalaran Matematis Siswa SMP

Mariyam $^{1}$, Rika Wahyuni ${ }^{2}$, Muhammad Andre Setiawan ${ }^{3}$

Berdasarkan Tabel 7 dapat dilihat bahwa rata-rata motivasi belajar siswa untuk pernyataan positif dari kelima indikator tersebut secara keseluruhan memiliki kriteria tinggi dengan nilai rata-rata keseluruhan 4,07. Indikator 1 terdiri dari 2 pernyataan yaitu siswa memiliki rasa ingin tahu yang kuat terhadap pembelajaran matematika dan selalu berdiskusi dengan teman saat mengikuti pembelajaran matematika menggunakan model pembelajaran VAK. Indikator 2 terdiri dari 3 pernyataan yaitu mengikuti pembelajaran matematika dengan baik, merasa tugas matematika lebih menarik dan memiliki semangat menyelesaikan tugas matematika melalui model pembelajaran VAK. Indikator 3 terdiri dari 2 pernyataan yaitu tekun dalam menyelesaikan tugas dan fokus mendengarkan pendapat teman saat berdiskusi melalui model pembelajaran VAK. Indikator 4 terdiri dari 2 pernyataan yaitu tidak mudah menyerah dan akan mencari tahu jawaban yang benar dari tugas yang diberikan melalui model pembelajaran VAK. Indikator 5 terdiri dari 3 pernyataan yaitu siswa termotivasi mendapatkan nilai yang tinggi, berusaha keras menyelesaikan tugas sampai tuntas dan bersungguh-sungguh membantu teman kelompok melalui model pembelajaran VAK. Hasil perhitungan rata-rata angket motivasi belajar siswa pernyataan negatif pada kelas eksperimen menggunakan model pembelajaranVAK dapat dilihat pada Tabel 8 berikut

\section{Tabel 8. Rekapitulasi Hasil Angket Motivasi Belajar Siswa untuk Pernyataan Negatif}

\begin{tabular}{|c|c|c|c|c|c|c|c|}
\hline \multirow{2}{*}{ Indikator } & \multicolumn{5}{|c|}{ Jumlah Siswa tiap Pilihan } & \multirow{2}{*}{$\begin{array}{l}\text { Rata- } \\
\text { rata }\end{array}$} & \multirow{2}{*}{ Kriteria } \\
\hline & SS & $\mathrm{S}$ & $\mathrm{RR}$ & TS & STS & & \\
\hline $\begin{array}{l}\text { 1. Adanya dorongan dan kebutuhan } \\
\text { dalam belajar }\end{array}$ & 2 & 3 & 3 & 25 & 23 & 4,14 & Tinggi \\
\hline $\begin{array}{l}\text { 2. Menunjukan perhatian dan minat } \\
\text { terhadap tugas-tugas yang diberikan }\end{array}$ & 2 & 5 & 9 & 13 & 55 & 4,35 & Tinggi \\
\hline 3. Tekun menghadapi tugas & 2 & 3 & 2 & 12 & 9 & 3,82 & Tinggi \\
\hline 4. Ulet menghadapi kesulitan & 2 & 5 & 18 & 17 & 14 & 3,64 & Tinggi \\
\hline $\begin{array}{l}\text { 5. Adanya hasrat dan keinginan } \\
\text { berhasil }\end{array}$ & 2 & 6 & 4 & 24 & 20 & 3,96 & Tinggi \\
\hline Rata-Rata Keseluruhan & & & & & & 3,98 & Tinggi \\
\hline
\end{tabular}

Berdasarkan Tabel 8 dapat dilihat bahwa rata-rata motivasi belajar siswa untuk pernyataan negatif dari kelima indikator tersebut secara keseluruhan memiliki kriteria tinggi dengan nilai rata-rata keseluruhan 3,98. Pada indikator 1 terdiri dari 2 pernyataan yaitu siswa tidak memiliki dorongan untuk belajar matematika dan menganggap pembelajaran matematika dengan model VAK. Indikator 2 yang terdiri dari 3 pernyataan yaitu siswa tidak suka saat diberi banyak tugas, menganggap belajar matematika dengan model VAK malah membuat malas untuk berdiskusi dengan teman dan belajar dengan cara mencatat apa saja yang ditulis guru lebih menyenangkan daripada harus belajar menemukan sendiri materi yang diajarkan. Indikator 3 yang terdiri dari 1 pernyataan yaitu pada pembelajaran VAK siswa tidak teliti dalam mengerjakan tugas.Indikator 4 yang terdiri dari 2 pernyataan yaitu tidak tertarik dalam menyelesaikan tugas matematika yang dianggap sulit dan ragu-ragu dalam mengemukakan pendapat saat pembelajaran dengan model VAK. Indikator 5 yang terdiri dari 2 pernyataan yaitu tidak terlalu peduli jika tidak bisa mengerjakan tugas berkelompok dengan model VAK dan soal yang tidak dapat dikerjakan dibiarkan saja, tunggu guru yang menjelaskannya di papan tulis. 
Secara keseluruhan rata-rata motivasi belajar siswa baik dari pernyataan positif dan pernyataan negatif dapat dilihat pada Tabel 9.

Tabel 9. Rekapitulasi Hasil Angket Motivasi Belajar Siswa untuk Seluruh Indikator

\begin{tabular}{llllllll}
\hline \multirow{2}{*}{ Pernyataan } & \multicolumn{9}{l}{ Jumlah Siswa tiap Pilihan } & \multirow{2}{*}{ Rata-rata } & \multirow{2}{*}{ Kriteria } \\
\cline { 2 - 6 } & SS & S & RR & TS & STS & & \\
\hline Positif & 125 & 143 & 44 & 18 & 6 & 4,08 & Tinggi \\
Negatif & 10 & 22 & 36 & 91 & 121 & 3,93 & Tinggi \\
\hline Rata-Rata Keseluruhan & & & & $\mathbf{4 . 0 0 5}$ & Tinggi \\
\hline
\end{tabular}

Berdasarkan Tabel 9 dapat dilihat bahwa rata-rata motivasi belajar siswa untuk pernyataan positif dan negatif pada semua indikator berada pada kriteria tinggi dengan jumlah 28 siswa menghasilkan rata-rata keseluruhan siswa adalah 4,005 dengan kriteria tinggi karena berada pada kisaran $3,4<\bar{X} \leq 4,2$. Motivasi diperlukan untuk mengarahkan seseorang agar melakukan suatu tindakan.Satu diantara kelebihan dari model pembelajaran VAK menurut Kartikasari (2011) adalah siswa dapat belajar dengan baik jika mereka dapat melihat contoh dari dunia nyata, diagram, peta gagasan, ikon, gambar, dan gambaran dari segala macam hal ketika mereka sedang belajar.

Tingginya motivasi belajar siswa kelas eksperimen pada penelitian ini dikarenakan pada model pembelajaran VAK, siswa tidak langsung diberikan hasil akhir dari penyelesaian, melainkan siswa dilatih untuk belajar menyelesaikan masalah dengan cara sendiri melalui diskusi bersama teman sekelompoknya dengan bantuan guru sehingga menimbulkan keingintahuan mereka untuk bisa menyelesaikan masalah yang secara tidak langsung memotivasi keinginan siswa untuk belajar. Hal ini sejalan dengan hasil penelitian yang dilakukan oleh Purwanto (2012) diperoleh hasil belajar siswa meningkat dari 68\% (sedang) pada siklus 1 menjadi 77\% (tinggi) pada siklus 2. Hal ini berarti bahwa model pembelajaran VAK berpengaruh terhadap motivasi belajar siswa pada pembelajaran matematika.

\section{KESIMPULAN}

Berdasarkan hasil penelitian dapat disimpulkan bahwa: (1) model pembelajaran VAK dapat dijadikan alternatif dalam mengembangkan kemampuan penalaran matematis pada materi relasi dan fungsi kelas VIII SMP Negeri 4 Singkawang; (2) terdapat perbedaan peningkatan kemampuan penalaran matematis antara siswa yang mendapatkan model pembelajaran VAK) dengan siswa yang mendapatkan model pembelajaran langsung pada materi aljabar relasi dan fungsi, serta peningkatan di kelas eksperimen lebih tinggi dibandingkan peningkatan yang ada dikelas kontrol; dan (3) Pada kelas eksperimen dilakukan pengamatan aktivitas belajar siswa yang hasilnya selama diterapkannya model pembelajaran Visualisation, Auditory, Kinesthetic (VAK), aktivitas belajar siswa pada tiap indikator pengamatan berada pada kriteria sangat tinggi sehingga termasuk ke dalam aktivitas aktif dan berdasarkan hasil angket diperoleh bahwa rata-rata motivasi belajar siswa terhadap penerapan model pembelajaran Visualisation, Auditory, Kinesthetic (VAK) tergolong tinggi.

\section{REFERENSI}

Arkasari, T. R., Hobri, H., \& Sugiarti, T. 2014. "IMPLEMENTASI KURIKULUM TINGKAT SATUAN PENDIDIKAN PLUS OLEH GURU MATEMATIKA DI 
Penerapan Model Pembelajaran Visualization, Auditory, Kinesthetic Terhadap Kemampuan Penalaran Matematis Siswa SMP

Mariyam $^{1}$, Rika Wahyuni ${ }^{2}$, Muhammad Andre Setiawan ${ }^{3}$

RINTISAN SEKOLAH BERTARAF INTERNASIONAL (RSBI) SMPN 3 JEMBER" dalam jurnal Pancaran Pendidikan, Volume 3 No. 4, Hal.193204.Januari 2015.

Hanafiah, C Suhana. 2009. Konsep Strategi Pembelajaran. Bandung: RefrikaAditama.

Huda, Miftahul. 2013. Model-model Pengajaran dan Pembelajaran, Yogyakarta: Pustaka Pelajar.

Kartikasari. 2011. Belajar dan Pembelajaran. Jakarta: Bumi Aksara.

Lestari, K. E., \& Yudhanegara, M. R. (2015). Penelitian pendidikan matematika: Panduan praktis menyusun skripsi (Doctoral dissertation, Tesis, dan Laporan Penelitian dengan Pendekatan Kuantitatif, Kualitatif dan Kombinasi Disertai dengan Model Pembelajaran dan Kemampuan Matematis. Bandung: PT Refika Aditama

Mariyam, M \& Wahyuni R, .2016. "Mengembangkan Kemampuan Penalaran Matematis Siswa Melalui Problem Centered Learning Pada Materi Peluang (Study Eksperimen Di Kelas VIII SMP N 6 Singkawang)" dalam Jurnal Pendidikan Matematika Indonesia) Volume 1 No. 2, hal.74-80. September 2016 (Terakreditasi).

Mikrayanti, 2012. Meningkatkan kemampuan penalaran dankomunikasi matematis siswasekolah menengah atas melaluipembelajaran berbasis masalah. Bandung: UPI

Musthafa, R.A.,Sunardi S. \& Fatahillah A. (2014). "Analisis Tingkat Kemampuan Penalaran Siswa dalam Menyelesaikan Soal Cerita Materi FPB dan KPK Kelas VII B SMP Negeri 10 Jember".Jurnal Edukasi 1-6. November 2014.

National Council of Teacher of Mathematics (NCTM). (2000). Principles and Standars for School Mathematics.Virginia: Reston.

Peraturan Menteri No. 59 (2014).Kurikulum SMA lampiran III, PMP MTK SMA.

Purwanto, (2012). Evaluasi Pembelajaran. Yogyakarta: Multi Pressindo.

Shoimin, Aris. 2014. Model Pembelajaran Inovatif dalam Kurikulum 2013. Yogyakarta: ArRuss Media.

Permana, Y., \& Sumarmo, U. (2007). Mengembangkan kemampuan penalaran dan koneksi matematik siswa SMA melalui pembelajaran berbasis masalah. Jurnal Educationist, 1(2), 116-123..(2007).

Sumarmo, U. (2013). Kumpulan makalah berpikir dan disposisi matematik serta pembelajarannya. Bandung: Fakultas Pendidikan Matematika dan Ilmu Pengetahuan Alam Universitas Pendidikan Indonesia Bandung. 